\title{
PENGARUH KARAKTER EKSEKUTIF, PROFITABILITAS, SALES GROWTH DAN CORPORATE SOCIAL RESPONSBILITY TERHADAP TAX AVOIDANCE PADA PERUSAHAAN NON-KEUANGAN YANG TERDAFTAR DI BURSA EFEK INDONESIA TAHUN 2011-2015
}

\author{
M. Qyas Aulia Ryzki *1, Raida Fuadi ${ }^{* 2}$ \\ ${ }^{1,2}$ Program Studi Akuntansi Fakultas Ekonomi dan Bisnis Universitas Syiah Kuala \\ e-mail: muhammadqyaz@gmail.com ${ }^{{ }^{1}}$, raidafuadi@yahoo.com ${ }^{* 2}$
}

\begin{abstract}
The source of state revenue that has a large contribution in financing government spending is obtained from taxes. Taxes are levies which can be imposed on taxpayers, both entities and individuals based on tax laws. This study entitled "The Influence of Executive Character, Profitability, Sales Growth, Corporate Social Responsibility (CSR) Against Tax Avoidance in Non-Financial Companies Listed on the Indonesia Stock Exchange Period 2011-2015". This study aims to determine whether the Independent variable executive character, Profitability, Sales Growth and Corporate Social Responsibility (CSR) affect Tax Avoidance as a Dependent variable. The sample of this study was 11 non-financial companies which were obtained based on the sampling criteria. The analytical method of this study uses a casual study method. The results of the study state that executive character variables, Profitability variables, Sales Growth variables and Corporate Social Responsibility (CSR) variables have a positive effect on tax avoidance or Tax Avoidance.
\end{abstract}

Keywords: Tax Avoidance, Executive Character, Profitabilitas, Sales Growth, Corporate SocialResponsibility (CSR).

\section{Pendahuluan}

Dalam berbagai sektor, manfaat dari pajak bisa dirasakan langsung dan tidak langsung. Fasilitas seperti pendidikan, transportasi, kesehatan, sarana dan prasarana umum merupakan hasil nyata dari pajak. Hal demikian menggambarkan pentingnya penerimaan pajak didalam hal pembangunan nasional, sehingga pemerintah pun melalui DJP (Direktorat Jenderal Pajak) melakukan banyak usaha untuk memaksimalkan dan meningkatkan penerimaan pajak (Jatmiko,2006).

Penghindaran pajak atau Tax Avoidance merupakan upaya untuk mengurangi beban pajak secara legal yang dilakukan dengan cara memanfaatkan ketentuan-ketentuan dibidang perpajakan secara optimal misalnya seperti pemotongan-pemotongan yang diperkenankan, maupun memanfaatkan beberapa hal yang belum diatur serta kelemahan-kelemahan yang ada didalam undang-undang perpajakan yang berlaku. Tax avoidance ini dapat dikatakan legal dikarena tidak bertentangan dengan undang-undang perpajakan yang berlaku melainkan dilakuakan dengan cara memanfaatkan celah dalam undang-undang perpajakan yang nantinya akan mempengaruhi penerimaan atau pendapatan negara dari segi pajak (Kurniasih dan Ratnasari, 2013). Jika penghindaran pajak melewati batas ataupun melanggar undang-undang perpajakan yang berlaku, maka aktivitas tersebut dapat digolongkan kedalam penggelapan pajak (tax evasion). Penggelapan pajak itu sendiri adalah usaha untuk mengurangi kewajiban pajak yang bersifat illegal (Prakosa,2014).

\section{Kajian Pustaka dan Kerangka Pemikiran Teori \\ Teori Egoisme}

Dilihat dari teori egoisme, Penghindaran pajak tidak bisa dikatakan sebagai tindakan yang melanggar, Karena tindakan mementingkan diri sendiri seperti ini bukanlah sebuah pelanggaran etika. Jadi perusahaan maupun pegawai pajak bisa dikatakan tindakan yang mementingkan diri sendiri. (Hutami, 2016)

\section{Teori Etika Hak dan Kewajiban (Emanuel Kant)}

Teori etika yang dikemukakan oleh Kant adalah teori hak dan kewajiban. Jelas sekali jika masalah 
penghindaran pajak erat kaitannya dengan teori hak dan kewajiban. Membayar pajak adalah suatu kewajiban perusahaam kepada negara serta kewajiban negara untuk memanfaatkan dana pajak didalam menyediakan fasilitas-fasilitas umum yang nantinya akan digunakan semua orang. (Hutami, 2016)

\section{Teori Etika Altruistic}

Altruistic approach (Bosco, 1997) adalah tindakan yang peduli pada orang lain atau dalam arti lain lebih mengutamakan kepentingan orang lain dengan cara mengorbankan kepentingan diri sendiri. Perusahaan melakukan pembayaran pajak agar nantinya bisa digunakan untuk mensejahterakan rakyatnya oleh negara. Kebanyakan Petugas dan perusahaan melanggar etika karena mementingkan diri sendiri dibanding kepentingan banyak orang. (Hutami, 2016)

\section{Teori Utilitarianisme}

Teori ini mengorbankan prinsip keadilan dan hak individu demi memperoleh banyak manfaat bagi orang banyak adalah hal yang diperbolehkan. Pemerintah sendiri berhak memberi penekanan pada perusahaan untuk melakukan pembayaran pajak. Hal ini dikarenaan dana yang terkumpul akan digunakan untuk kesejahteraan orang banyak. Jika dipautkan dengan Penghindaran pajak, maka dana pajak harusnya diterima negara dan digunakan sebaikbaiknya untuk kemakmuran rakyat bisa terwujud. (Hutami, 2016).

\section{Teori Tindakan Utama}

Sifat utama didalam berbisnis adalah kewajaran, kejujuran, keuletan dan kepercayaan. Tindakan penghindaran pajak merupakan tindakan yang melanggar kepercayaan, sangat tidak jujur dan bukan sebuah perbuatan yang wajar, baik dilakukan oleh wajib pajak maupun petugas pajaknya. Sehingga ketidakselarasan ini bisa dikatakan sebagai pelanggaran etika. (Hutami, 2016).

\section{Teori Etika Teonom}

Penghindaran pajak adalah sebuah tindakan melanggar agama, hal ini dikarenakan dalam agama disarankan untuk memberikan apa yang kita miliki dalam hal membantu sesama. Mc Gee (1997) menerangkan bahwa dalam berbagai agama (Islam,
Kristen, Katolik) pembayaran atas pajak dianjurkan dan diperbolehkan. Berarti artinya, jika tidak membayar pajak sesuai dengan yang sudah ditentukan merupaka tindakan yang tidak beretika serta bertentangan dengan agama. (Hutami, 2016)

\section{Tax Avoidance}

Penghindaran pajak atau Tax Avoidance merupakan upaya untuk mengurangi beban pajak secara legal yang dilakukan dengan cara memanfaatkan ketentuan-ketentuan dibidang perpajakan secara optimal misalnya seperti pemotongan-pemotongan yang diperkenankan, maupun memanfaatkan beberapa hal yang belum diatur serta kelemahan-kelemahan yang ada didalam undang-undang perpajakan yang berlaku (Suandy, 2005).

Tax avoidance yang dilakukan ini dapat dikatakan legal karena tidak bertentangan dengan undang-undang perpajakan yang berlaku melainkan dengan cara memanfaatkan celah-celah dalam undang-undang perpajakan tersebut yang akan mempengaruhi penerimaan negara dari sektor pajak (Kurniasih dan Ratnasari, 2013). Apabila penghindaran pajak tersebut melebihi batas atau melanggar undang-undang perpajakan yang berlaku, maka aktivitas tersebut dapat tergolong kedalam penggelapan pajak (tax evasion). Penggelapan pajak adalah usaha untuk mengurangi kewajiban pajak yang bersifat ilegal (Prakosa, 2014.

\section{Karakter Eksekutif}

Setiap keputusan yang ada di dalam suatu perusahaan, tentunya melibatkan eksekutif. Menurut Low (2006), dalam hal pengambilan keputusan, eksekutif perusahaan memiliki karakter yang sangat berbeda, yaitu eksekutif yang berani utnuk mengambil risiko (risk taker) dan eksekutif yang tidak berani mengambil risiko (risk averse).Low (2006) juga mengemukakan bahwa terdapat dua karakter yang biasanya dimiliki oleh seorang pimpinan eksekutif perusahaan, yaitu sebagai risk taker dan risk averse.

Karakter eksekutif risk taker adalah adalah eksekutif yang lebih berani dalam hal pengambilan keputusan bisnis dan biasanya memiliki dorongan yang cukup kuat untuk memiliki income, posisi, kesejahteraan, dan kewenangan yang lebih tinggi (Maccrimon dan Wehrung,1990). Eksekutif yang 
memiliki karakteristik risk taker tidak ragu-ragu untuk melakukan pembiayaan dari hutang, hal ini dilakukan agar perusahaan dapat tumbuh dengan cepat (Lewellen, 2003).

\section{Profitabilitas}

Pofitabilitas merupakan kemampuan perusahaan dalam menghasilkan laba pada masa mendatang dan juga sebagai tolak ukur dari keberhasilan operasi perusahaan dalam satu periode tertentu (Arfani, 2005). Didalam peneilitiannya, Sujoko dan Soebiantoro (2007) menjelaskan pofitabilitas adalah kemampuan sebuah perusahaan untuk menghasilkan income selama 1 tahun yang dilihat dalam rasio laba operasidengan penjualan dari laba rugi akhir tahun. Dasar penilaian dari pofitabilitasini adalah laporan keuangan.

Pada penelitian ini, ROA digunakan sebagai rasio pofitabilitas untuk mengukur tingkat pofitabilitas perusahaan karena ROA menunjukkan efektifitas perusahaan dalam mengelola aset baik modal sendiri maupun modal pinjaman. Dengan demikian, investor akan melihat seberapa efektif perusahaan dalam mengelola aset. ROA juga mampu mengukur kemampuan perusahaan dalam menghasilkan keuntungan pada masa lampau untuk kemudian diproyeksikan dimasa mendatang. Semakin tinggi ROA, maka semakin tinggi keuntungan perusahaan sehingga semakin baik pengelolaan asset perusahaan (Rinaldi, 2015).

\section{Sales Growth}

Pertumbuhan penjualan menggambar kan sebuah pencapaian investasi periode masa lalu perusahaan dan bisa dijadikan sebagai patokan pertumbuhan masa yang akan datang. Pertumbuhan penjualan juga merupakan indikatorpermintaan dan daya saing sebuah perusahaan didalam sebuah industri. Laju partumbuhan penjualan suatu perusahaan sanat mempengaruhi kemampuan perusahaan tersebut dalam mempertahankan laba untuk mendanai kesempatan yang dimiliki pada masa yang akan datang. Jika pertumbuhan penjualan meningkat, maka akan menggambarkan profit yang meningkat. Sehingga pembayaran dividen cenderung meningkat (Barton et al., 1989 dalam Deitiana, 2011).

Menurut Devie (2003), pertumbuhan penjualan sebuah perusahaan akan menimbulkan penyebab peningkatan investasi atas aset perusahaan tersebut dan akhirnya perusahaan tersebut buth asupan dana untuk membeli asset perusahaan. Dengan kata lain, pertumbuhan penjualan mempengaruhi keputusan pembiayaan dan investasi perusahaan. Pada penelitian ini, sales growth menggunakan proksi pertumbuhan penjualan dengan rumus penjualan akhir periode dikurangi penjualan awal periode dibagi penjualan awal periode (Dyreng et. al., 2009).

\section{Harga Pokok Produksi}

Harga pokok produksi adalah segala biaya yang berkaitan dengan barang ataupun produk yang didapatkan, yang terdiri biaya bahan baku, biaya tenaga kerja langsung, dan biaya overhead pabrik (Nafarin, 2009: 497). Kartadinata (2008: 38) juga menjelaskan bahwa definisi dari harga pokok produksi yaitu seluruh biaya dan pengeluaran yang harus dikorbankan untuk menghasilkan barang jadi.

\section{Corporate Social Responsibility (CSR)}

Secara umum, CSR dapat diartikan sebagai bagaimana perusahaan tidak hanya bertanggungjawab dengan shareholder namun juga bertanggungjawab kepada stakeholder dalam menciptakan nilai jangka panjang. Menurut Baker (2003) CSR adalah tentang bagaimana perusahaan mengelola bisnis untuk menghasilkan dampak positif kepada masyarakat. Sedangkan menurut Milton Friedman dalam Solihin (2009) CSR adalah menjalankan bisnis sesuai dengan keinginan pemilik $\mathrm{p}$ erusahaan dengan menghasilkan keuntungan yang sebesar-besarnya tanpa melanggar aturan masyarakat yang diatur hukum dan peraturan perundang-undangan. Namun menurut Suharto (2008) dalam Sayidati (2011) CSR adalah operasi yang tidak semata berfokus pada keuntungan finansial, melainkan untuk pembangunan ekonomi berkelanjutan

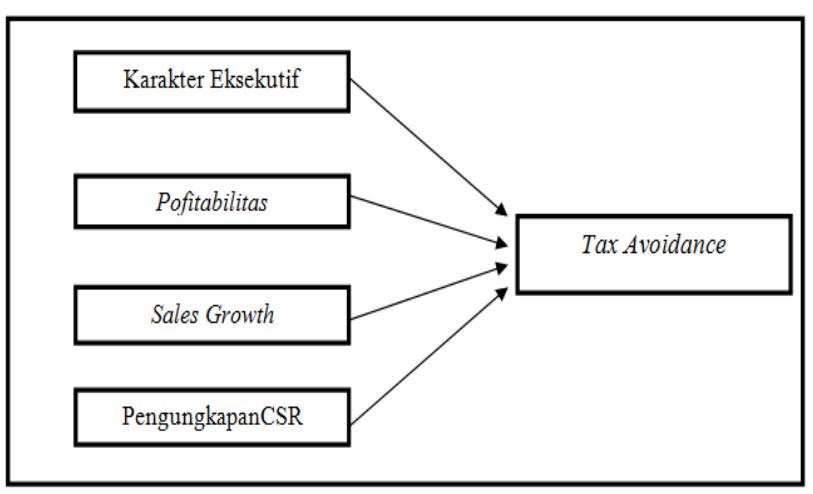

Gambar 2.1. Kerangka Pemikiran 


\section{Metode Penelitian}

\section{Desain Penelitian}

Jenis investigasi dalam penelitian ini yaitu studi kausal (causal study). Studi kausal adalah studi yang dilakukan untuk menemukan penyebab dari satu atau lebih masalah (Sekaran, 2006:165). Penelitian ini menganalisis pengaruh variabel-variabel terhadap tax avoidance. Tingkat intervensi dalam penelitian ini adalah intervensi minimal. Peneliti hanya mengumpulkan data berupa laporan tahunan perusahaan dan laporan keberlanjutan perusahaan yang kemudian dianalisis tanpa mengintervensi data yang diteliti.

\section{Sumber dan Teknik PengumpulanData}

Sumber data dalam penelitian ini adalah data sekunder. Teknik pengumpulan data yang digunakan dalam penelitian ini adalah dokumentasi, yaitu pengumpulan data yang diperoleh dari laporan tahunan dan laporan keberlanjutan perusahaan nonkeuangan yang terdaftar di BEI pada periode 20112015. Data diperoleh dari BEI atau dari website milik BEI yaitu www.idx.co.id, serta sumber lain yang relevan seperti dari website resmi perusahaan..

\section{Rancangan Pengujian Hipotesis \\ Pengujian Asumsi Klasik}

Pengujian asumsi klasik dalam penelitian ini adalah sebagai berikut:

\section{Uji Normalitas}

Uji normalitas bertujuan untuk menguji apakah dalam metode regresi, variabel pengganggu atau residual memiliki distribusi normal. Seperti diketahui bahwa uji $\mathrm{t}$ dan uji $\mathrm{F}$ mengasumsikan bahwa nilai residual mengikuti distribusi normal (Ghozali, 2009:110). Untuk menguji apakah data berdistribusi normal digunakan uji Kolmogorov-Smirnov. Distribusi data dikatakan normal jika signifikansi > 0.05 (Ghozali, 2009:125). Jika $\mathrm{p}<0.05$ maka data tersebut merupakan data yang tidak normal distribusinya.

Hal ini dikarenakan setelah dilakukan perbandingan ternyata data tersebut berbeda dengan kurva normal, sehingga data tersebut merupakan data yang tidak normal distribusinya. Sebaliknya, jika $\mathrm{p}>$ 0.05 maka data yang dimiliki adalah data yang mempunyai distribusi normal, karena setelah dilakukan uji perbandingan ternyata data yang dimiliki tidak berbeda dengan kurva normal. Ukuran inilah yang digunakan untuk menentukan apakah data tersebut berasal dari populasi yang normal atau tidak.

\section{Uji Multikolinieritas}

Uji Multikolinieritas merupakan hubungan linier antara variabel independen dalam regresi berganda. Model regresi yang baik seharusnya tidak terjadi korelasi antara variabel bebas, jika variabel ini saling berkorelasi berarti ini tidak ortogonal (Ghozali, 2009:91). Untuk mendeteksi ada tidaknya multikolinieritas dalam model regresi dilakukan dengan menganalisis nilai tolerance dan lawannya Variance Inflation Factor (VIF). Nilai tolerance yang rendah sama dengan nilai VIF tinggi, karena VIF = 1/tolerance. Nilai cutoff yang umum dipakai untuk menunjukkan adanya multikolinieritas adalah nilai tolerance $<0.10$ atau sama dengan nilai VIF $>10$ (Ghozali, 2009:91).

\section{Uji Heteroskedastisitas}

Uji heteroskedastisitas bertujuan untuk menguji apakah dalam model regresi terjadi ketidaksamaan variance dari residual suatu pengamatan yang lain. Jika variance dari residual satu pengamatan ke pengamatan lain tetap, maka disebut homoskedastisitas dan jika berbeda disebut heteroskedastisitas (Ghozali, 2009:105). Dalam penelitian ini untuk mendeteksi ada atau tidaknya heteroskedastisitas digunakan uji glejser.

\section{Uji Autokorelasi}

Uji Autokorelasi bertujuan untuk menguji apakah dalam suatu model regresi linier ada korelasi antara kesalahan penggangg (residual) pada periode $t$ dengan kesalahan pada periode t-1 (sebelumnya). Jika terjadi korelasi, maka dinamakan ada problem autokorelasi (Ghozali, 2009:95) Pengujian autokorelasi dilakukan dengan menggunakan uji Durbin Watson (Durbin Watson Test), yaitu untuk menguji apakah terjadi korelasi serial atau tidak dengan menghitung nilai $\mathrm{d}$, jika $\mathrm{d}<\mathrm{d} 1$ maka terdapat autokorelasi positif, jika $\mathrm{d}>(4-\mathrm{d} 1)$ maka terdapat autokorelasi negative, dimana "d" merupakan nilai Turbin Watson 


\section{Pengujian Hipotesis}

\section{Uji Signifikansi Simultan (Uji Statistik F)}

Uji F ini dilakukan untuk menguji apakah seluruh variabel independen secara bersama-sama (simultan) mempunyai pengaruh yang signifikan terhadap variabel dependen. Bila $\mathrm{F}_{\text {hit }}>\mathrm{F}_{\text {tabel }}$ dengan tingkat signifikansi 5\% maka dapat disimpulkan bahwa secara bersama-sama variabel independen berpengaruh signifikan terhadap variabel dependen. Jika $\mathrm{F}_{\text {hit }}<\mathrm{F}_{\text {tabel }}$ tingkat signifikansi 5\% maka dapat disimpulkan bahwa secara bersama-sama variabel independen tidak berpengaruh signifikan terhadap variabel dependen.

\section{Uji Signifikansi Parameter Individual (Uji Statistik} t)

Uji t digunakan untuk mengetahui seberapa jauh pengaruh suatu variabel independen secara individual dalam menjelaskan variasi variabel dependen (Ghozali, 2009). Pengujian dilakukan dengan menggunakan significance level $0.05(=5 \%)$. Penerimaan atau penolakan hipotesis dilakukan dengan kriteria sebagai berikut:

- Jika t-hitung < t-tabel atau jika nilai Sig $>0.05$ maka hipotesis ditolak (Koefisien regresi tidak signifikan). Hal ini berarti bahwa secara parsial variabel independen tersebut tidak mempunyai pengaruh terhadap variabel independen.
- Jika t-hitung > t-tabel atau jika nilai Sig $<0.05$ maka hipotesis diterima (koefisien regresi signifikan). Hal ini berarti bahwa secara parsial variabel independen tersebut mempunyai pengaruh terhadap variabel independen.

\section{Koefisien Determinasi $\left(\mathbf{R}^{2}\right)$}

Analisis koefisien determinasi digunakan untuk mengukur sejauh mana kemampuan model dalam menerapkan variasi variabel dependen. Nilai koefisien determinasi menunjukkan persentase pengaruh dari variabel independen terhadap variabel dependen yang dinyatakan dengan $\mathrm{R}$ square $\left(\mathrm{R}^{2}\right)$. Nilai koefisien determinasi berada diantara nol dan satu. Nilai $R^{2}$ yang kecil berarti kemampuan variabel-variabel bebas dalam menjelaskan variabel terikat amat terbatas. Nilai yang mendekati satu berarti variabel-variabel bebas memberikan hampir semua informasi yang dibutuhkan untuk memprediksi variasi variabel terikat (Ghozali, 2009:83)

\section{Hasil dan Pembahasan Statistik Deskriptif}

Uji statistik deskriptif digunakan untuk memberikan gambaran suatu data yang dilihat dari rata-rata (mean), deviasi standar, nilai maksimum dan nilai minimum dari masing-masing variabel yang akan diteliti. Hasil statistik deskriptif dari masing-masing variabel dapat dilihat pada Tabel 3 sebagai berikut.

Tabel 4.3

Hasil Uji Statistik Deskriptif

\begin{tabular}{|c|c|c|c|c|c|}
\hline & $\mathrm{N}$ & Min & Max & Mean & Std. Deviation \\
\hline RISK & 11 & 1,280 & 3,117 & 1,938 & 2,564 \\
\hline ROA & 11 & 1,120 & 2,610 & 1,920 & 2,191 \\
\hline GROWTH & 11 & 0,506 & 1,523 & 1,244 & 2,311 \\
\hline CSR & 11 & 1,064 & 3,198 & 2,624 & 3,448 \\
\hline CETR & 11 & 0,048 & 0,98 & 0,3211 & 0,19808 \\
\hline
\end{tabular}

Sumber: Hasil Output SPSS, 2019

Berdasarkan tabel 4.3 diatas, pengujian terhadap 11 sampel menunjukan bahwa variabel praktik penghindaran pajak memiliki, nilai rata-rata yaitu sebesar 0,3211 atau 32,11\%, hal ini berarti nilai ratarata (mean) CETR berada diatas tarif PPh berdasarkan UU PPh No 36 tahun 2008 Pasal 17 Ayat 2(b) yang ditetapkan (sebesar 20\%) yang berarti nilai CETR cukup tinggi dan kemungkinan adanya indikasi penghindaran pajaknya relatif rendah.

\section{Hasil Uji Asumsi Klasik \\ Uji Normalitas}


Tabel 4.4

Hasil Uji Normalitas

One-Sample Kolmogorov-Smirnov Test

Unstandardized Residual

\begin{tabular}{lrr}
\hline $\mathrm{N}$ & & 11 \\
Normal Parameters & Mean & 0,0000000 \\
& Std. Deviation & 0,16246976 \\
Most Extreme Difference & Absolute & 0,102 \\
& Positive & 0,102 \\
Kolmogorov-Smirnov Z & Negative & $-0,069$ \\
Asymp. Sig. (2-tailed) & & 0,936 \\
\hline
\end{tabular}

Sumber: Hasil Output SPSS, 2019

Gambar 4.1

Uji Normalitas Data dengan Normal Probability Plot

Normal P-P Plot of Regression Standardized

Residual

Dependent Variable: CETR

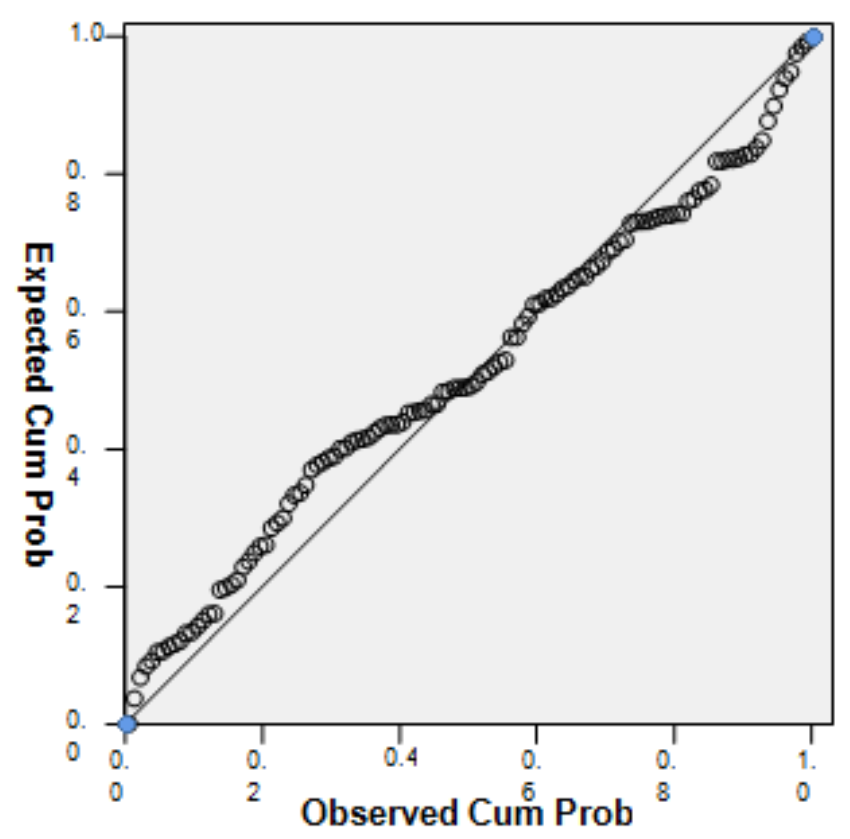

Sumber: Hasil Output SPSS, 2019 
3.1 Uji normalitas bertujuan untuk menguji apakah dalam model regresi, variabel pengganggu atau residual terdistribusi normal (Ghozali, 2016:154). Berdasarkan Tabel 4.4 dapat dilihat nilai Asymp. Sig. (2-tailed) sebesar 0,345 lebih besar dari tingkat signifikansi $\alpha=0,05$ maka dapat disimpulkan data yang dianalsis berdistribusi normal.

\section{Uji Multikolonieritas}

3.2 Pada Tabel 4.5 dibawah dapat dilihat bahwa nilai tolerance masing-masing variabel bebas lebih besar dari 0,1 dan nilai VIF kurang dari 10, sehingga dapat disimpulkan data yang dianalisis memenuhi asumsi multikolinearitas.

Tabel 4.5

Uji Multikolonieritas

\begin{tabular}{|c|c|c|c|c|c|c|c|}
\hline \multirow[t]{2}{*}{ Model } & \multicolumn{2}{|c|}{$\begin{array}{l}\text { Un } \\
\text { standardized } \\
\text { Coefficients }\end{array}$} & \multicolumn{2}{|c|}{$\begin{array}{l}\text { standardized T } \\
\text { Coefficients }\end{array}$} & \multirow[t]{2}{*}{ Sig. } & \multicolumn{2}{|l|}{$\begin{array}{l}\text { Collinearity } \\
\text { Statistics }\end{array}$} \\
\hline & B & $\begin{array}{l}\text { Std. } \\
\text { Error }\end{array}$ & Beta & & & Tolerance & VIF \\
\hline (constant) & 0,5 & 0,102 & & 5,410 & 0,000 & & \\
\hline RISK & & 0,085 & 0,006 & 0,055 & 0,957 & 0,974 & 1,026 \\
\hline $\mathrm{ROA}$ & & 0,003 & $-0,370$ & $-3,380$ & 0,001 & 0,878 & 1,140 \\
\hline GROWTH & 0,5 & 5,001 & 0,002 & 0,019 & 0,985 & 0,893 & 1,120 \\
\hline CSR & 1,0 & $+0,002$ & $-0,235$ & $-2,243$ & 0,028 & 0,959 & 1,042 \\
\hline
\end{tabular}

\section{a. Dependent Variable: ETR}

Sumber: Hasil Output SPSS, 2019

\section{Uji Heteroskedastisitas}

\section{Tabel 4.6}

Uji Heteroskedastisitas

\begin{tabular}{|c|c|c|c|c|c|}
\hline \multirow[t]{2}{*}{ Model } & \multicolumn{2}{|c|}{ Unstandardized Coefficients } & \multirow{2}{*}{$\begin{array}{c}\text { Standardized Coefficients } \\
\text { Beta }\end{array}$} & \multirow[t]{2}{*}{$\mathrm{T}$} & \multirow[t]{2}{*}{ Sig. } \\
\hline & B & Std. Error & & & \\
\hline (constant) & 0,178 & 0,062 & & 2,869 & 0,105 \\
\hline RISK & $-0,116$ & 0,052 & $-0,228$ & $-2,252$ & 0,127 \\
\hline ROA & $-0,006$ & 0,002 & $-0,363$ & $-3,359$ & 0,201 \\
\hline GROWTH & 0,000 & 0,001 & $-0,067$ & $-0,629$ & 0,531 \\
\hline CSR & 0,001 & 0,001 & 0,095 & 0,930 & 0,355 \\
\hline
\end{tabular}

a. Dependent Variable: ETR

3.3 Sumber: Hasil Output SPSS, 2019 


\section{Uji Autokorelasi}

Tabel 4.7

Uji Autokorelasi

Model Summary

\begin{tabular}{rlrrrr}
\hline Model & R & \multicolumn{1}{c}{ R Square } & \multicolumn{1}{c}{ Adjust R Square } & Std. Error of the Estimate & \multicolumn{1}{c}{ Durbin-Watson } \\
\hline 1 & $0,058^{\mathrm{a}}$ & 0,003 & $-0,006$ & 0,12303249 & 1,998 \\
\hline
\end{tabular}

a. Predictors: (constant), Lag_Res, RISK, ROA, GROWTH, CSR

b. Dependent Variable: RES_2

Sumber: Hasil Output SPSS, 2019

Berdasarkan hasil tabel 4.7 menunjukan hasil pengujian autokolerasi menggunakan empat proksi variabel independen setelah penambahan Lag dari nilai residual variabel terikat menjadi salah satu variabel bebasnya. Nilai Durbin-Watson yang dihasilkan yaitu sebesar 1,998 . Sedangkan, nilai $\mathrm{dL}=1,534$ dan nilai $\mathrm{dU}=1,743$, sedangkan nilai 4-dU $=2,257$. Nilai d yang dihasilkan terletak diantara batas atas atau upper bound (dU) dan (4-dU), maka autokolerasi $=0$, atau $1,743<1,998<2,257$. Maka Keputusannya adalah tidak ditolak dan hipotesis nol menyatakan tidak ada autokolerasi positif dan negatif dalam model regresi

\section{Hasil pengujian Hipotesis \\ Analisis Regresi Linear Berganda}

Tabel 4.8

Uji Regresi Linier Berganda

\begin{tabular}{lccccc}
\hline \multicolumn{1}{c}{ Model } & \multicolumn{2}{c}{ Unstandardized Coefficients } & Sstandardized Coefficients & T & Sig. \\
& $\mathrm{B}$ & Std. Error & Beta & & \\
\hline (constant) & 0,458 & 0,084 & & 5,417 & 0,000 \\
RISK & 0,322 & 0,068 & 0,003 & $-0,318$ & 0,072 \\
ROA & $-0,106$ & 0,002 & $-0,289$ & $-2,569$ & 0,002 \\
GROWTH & 0,121 & 0,001 & 0,159 & $-1,413$ & 0,022 \\
CSR & $-0,204$ & 0,001 & $-0,303$ & $-2,869$ & 0,005 \\
\hline
\end{tabular}

a. Dependent Variable: ETR

Sumber: Hasil Output SPSS, 2019

Berdasarkan Tabel 4.8 di atas dapat dibuat persamaan regresi sebagai berikut. $\mathrm{Y}=0,458+0,322$ RISK - 0,106 ROA + 0,121 GROWTH - 0,204 CSR + e. Penjelasan dari persamaan model regresi tersebut diuraikan sebagai berikut: Nilai konstanta $(\alpha)$ sebesar 0,458 artinya apabila variabel-variabel bebas Karakter Eksekutif (X1), Profitabilitas (X2),Sales Growth (X3) dan CSR (X4) diasumsikan konstan pada nilai nol maka nilai Y (ETR) naik sebesar 0,458 atau sebesar $45,8 \%$. Koefisien regresi variabel Karakter Eksekutif sebesar 0,022 , hal ini berarti apabila nilai variabel Karakter Eksekutif mengalami kenaikan sebesar 1 satuan dan variabel lain nilainya konstan, maka variabel dependen yaitu praktik penghindaran pajak yang diproksikan dengan Effective Tax Rate (ETR) akan mengalami kenaikan sebesar 0,022 atau 2,2\%.

Koefisien regresi variabel profitabilitas sebesar
$-0,006$, hal ini berarti apabila nilai variabel profitabilitas mengalami kenaikan sebesar $1 \%$ dan variabel lain nilainya konstan, maka variabel dependen yaitu praktik penghindaran pajak yang diproksikan dengan Effective Tax Rate (ETR) akan mengalami penurunan sebesar $0,6 \%$.

Koefisien regresi variabel Sales Growth sebesar 0,121 , hal ini menunjukan koefisien regresi tersebut sangat kecil, dan berarti apabila nilai variabel Sales Growth mengalami kenaikan sebesar 1\% dan variabel lain nilainya konstan, maka variabel dependen yaitu praktik penghindaran pajak yang diproksikan dengan Effective Tax Rate (ETR) akan mengalami kenaikan sebesar $0,1 \%$.

Koefisien regresi variabel CSR sebesar $-0,004$, hal ini berarti apabila nilai variabel komisaris independen mengalami kenaikan sebesar $1 \%$ dan 
variabel lain nilainya konstan, maka variabel dependen yaitu praktik penghindaran pajak yang diproksikan dengan Effective Tax Rate (ETR) akan mengalami penurunan sebesar $0,4 \%$

\section{Koefisien Determinasi}

Tabel 4.9

Hasil Uji Koefisien Determinasi Model Summary

\begin{tabular}{|c|c|c|c|c|}
\hline Model & $\mathrm{R}$ & $\begin{array}{l}\mathrm{R} \\
\text { Square }\end{array}$ & $\begin{array}{l}\text { Adjust R } \\
\text { Square }\end{array}$ & $\begin{array}{l}\text { Std. Error of } \\
\text { the Estimate }\end{array}$ \\
\hline 1 & $0,649 \mathrm{a}$ & 0,568 & 0,396 & 0,2435 \\
\hline
\end{tabular}

a. Predictors: (constant), Lag_Res, RISK, ROA, GROWTH, CSR

Sumber: Hasil Output SPSS, 2019

Dapat diketahui bahwa nilai R2 sebesar 0,568, nilai ini menunjukan bahwa variabel independen yaitu Karakter Eksekutif, Profitabilitas, SalesGrowth dan CSR dapat menjelaskan variasi variabel dependen yaitu praktik penghindaran pajak yang diproksikan dengan Effective Tax Rate (ETR) sebesar 56,8\% dan sisanya sebesar $43,2 \%$ dipengaruhi oleh variabel lain diluar model regresi seperti ukuran perusahaan, kepemilikan keluarga, likuiditas dll.

\section{Uji Signifikansi Bersama-sama (Uji Statistik F)}

Tabel 4.10

Hasil Uji Koefisien Determinasi

Model Summary

\begin{tabular}{llrrrr}
\hline Model & & $\begin{array}{l}\text { Sum of df } \\
\text { Squares }\end{array}$ & $\begin{array}{l}\text { Mean F } \\
\text { Square }\end{array}$ & Sig. \\
\hline \multirow{3}{*}{1} & Regression & 0,323 & 4 & 0,081 & $4,3710,002^{\text {b }}$ \\
& Residual & 1,278 & 75 & 0,017 & \\
& Total & 1,601 & 79 & & \\
\hline
\end{tabular}

Sumber: Hasil Output SPSS, 2019

Berdasarkan Tabel 4.10 memperlihatkan nilai signifikansi $\mathrm{F}$ sebesar 0,002 lebih kecil dari $\alpha=0,05$ sehingga dapat disimpulkan bahwa model ini layak digunakan dalam penelitian dan dapat digunakan untuk memprediksi variabel dependen
Uji Signifikansi Parameter Individual (Uji Statistik t)

Tabel 4.11

Hasil Uji Signifikansi Parameter Individual (Uji Statistik t)

\begin{tabular}{lrlrrr}
\hline Model & \multicolumn{3}{l}{$\begin{array}{l}\text { Unstandardized Sstandardized T } \\
\text { Coefficients }\end{array}$} & Sig. \\
& \multicolumn{2}{c}{ Std. } \\
\multicolumn{7}{c}{ Error } & Beta & & & \\
\hline (constant) & 0,458 & 0,084 & & 5,417 & 0,000 \\
RISK & 0,322 & 0,068 & 0,003 & $-0,318$ & 0,032 \\
ROA & $-0,106$ & 0,002 & $-0,289$ & $-2,569$ & 0,008 \\
GROWTH & 0,121 & 0,001 & 0,159 & $-1,413$ & 0,022 \\
CSR & $-0,204$ & 0,001 & $-0,303$ & $-2,869$ & 0,005
\end{tabular}

a. Dependent Variable: ETR

Sumber: Hasil Output SPSS, 2019

Berdasarkan tabel 4.11, dapat diketahui bahwa hasil Uji Statistik t menunjukan semua variabel yang memiliki nilai signifikansi dibawah 0,05 . Hal ini menunjukan bahwa variabel profitabilitas dan komisaris independen tersebut berpengaruh signifikan terhadap praktik penghindaran pajak yang diproksikan dengan Effective Tax Rate (ETR)

\section{Pembahasan Hasil Pengujian Hipotesis}

Pengaruh Karakter eksekutif terhadap Tax Avoidance

Hipotesis pertama (H1) menyatakan preferensi risiko eksekutif berpengaruh positif pada penghindaran pajak. Hasil analisis pada Tabel 4.7 menyatakan nilai signifikansi sebesar $0,032<0,05$. Hasil tersebut menunjukkan bahwa preferensi risiko eksekutif berpengaruh terhadap ETR yang menjadi proksi dari penghindaran pajak. Nilai koefisien $-0,318$ menunjukkan hasil yang negatif artinya semakin tinggi nilai risiko perusahaan (RISK) yang menjadi proksi dari preferensi risiko eksekutif maka semakin rendah nilai ETR. Nilai ETR yang semakin rendah mengindikasikan semakin tinggi tindakan penghindaran pajak. Disimpulkan bahwa semakin tinggi risiko perusahaan (RISK) berarti semakin tinggi tindakan penghindaran pajak

\section{Pengaruh Profitabilitas terhadap Tax Avoidance}

Variabel Profitabilitas yang diproksikan dengan ROA menunjukan nilai signifikansi sebesar 0,012. Hal 
ini berarti bahwa nilai signifikans $<0,05$ dan menunjukan koefisien regresi yang negatif sebesar 0,289 , sehingga dapat disimpulkan bahwa variabel profitabilitas yang diproksikan dengan ROA memiliki pengaruh positif terhadap praktik penghindaran pajak yang diproksikan dengan Effective Tax Rate (ETR). Dengan demikian, hipotesis kedua yang menyatakan bahwa variabel profitabilitas berpengaruh negatif terhadap praktik penghindaran pajak dapat diterima.

\section{Pengaruh Sales Growth terhadap Tax Avoidance}

Hipotesis ketiga (H3) menyatakan Sales Growth berpengaruh positif pada penghindaran pajak. Hasil analisis pada Tabel 4.7 menyatakan nilai signifikansi sebesar $0,022<0,05$. Hasil tersebut menunjukkan bahwa Sales Growth berpengaruh terhadap ETR yang menjadi proksi dari penghindaran pajak. Oleh karena itu, hipotesis H3 yang menyatakan Sales Growth berpengaruh positif pada penghindaran pajak diterima

\section{Pengaruh Corporate Social Reponsibility (CSR) terhadap Tax Avoidance}

Variabel Corporate Social Reponsibility(CSR) menunjukan nilai signifikansi sebesar 0,005. Hal ini berarti bahwa nilai signifikansi $<0,05$ dan dapat disimpulkan bahwa variabel corporate social responsibility (CSR) berpengaruh positif signifikan terhadap praktik penghindaran pajak yang diproksikan dengan Effective Tax Rate (ETR). Dengan demikian, hipotesis pertama yang menyatakan bahwa variabel corporate social responsibility berpengaruh positif terhadap praktik penghindaran pajak dapat diterima. Berdasarkan hasil pengujian yang telah dilakukan menunjukkan bahwa CSR berpengaruh positif terhadap penghindaran pajak. Artinya semakin tinggi tingkat pengungkapan CSR suatu perusahaan, maka akan semakin tinggi tingkat penghindaran pajak perusahaan.

\section{Kesimpulan, Keterbatasan dan Saran}

\section{Kesimpulan}

Berdasarkan hasil analisis data dan pembahasan yang telah dijelaskan pada bab sebelumnya, dapat disimpulkan bahwa:

1) Karakter Eksekutif berpengaruh positif pada penghindaran pajak. Karakter eksekutif yang diproksikan dengan risiko perusahaan dapat mempengaruhi tindakan penghindaran pajak perusahaan. Semakin tinggi risiko perusahaan yang mencerminkan eksekutif bersifat risk taker maka semakin tinggi tingkat penghindaran pajak perusahaan.

2) Profitabilitas yang diproksikan dengan ROA memiliki pengaruh positif terhadap praktik penghindaran pajak yang diproksikan dengan Effective Tax Rate (ETR) non keuangan yang terdaftar di Bursa Efek Indonesia tahun 20112015.

3) Sales Growth berpengaruh positif pada penghindaran pajak. semakin besar sales growth suatu perusahaan maka CETR akan semakin kecil, semakin kecil nilai CETR mengindikasikan tingginya tingkat penghindaran pajak. dengan meningkatnya laba perusahaan yang diperoleh dari hasil pertumbuhan pen jualan mengindikasikan pimpinan perusahaan tersebut telah berusaha memaksimalkan nilai perusahaan dimana itu merupakan tugas seorang agent terhadap principal dalam teori keagenan.

4) Corporate Social Responsibility (CSR) berpengaruh positif pada penghindaran pajak. Semakin tinggi perusahaan mengungkapkan CSR, maka semakin tinggi tindakan penghindaran pajak perusahaan. Hal tersebut dikarenakan aktifitas CSR yang dilakukan masih dianggap sebagai beban dan bukan lagi sebagai bagian dari pengembangan masyarakat. Rusydi dan Veronica (2014) juga menjelaskan bahwa perusahaan yang selama ini menyatakan telah melaksanakan aktivitas CSR, ternyata banyak yang tersangkut masalah pidana perpajakan dalam hal ini penghindaran pajak seperti halnya kasus PT. Asian Agri yang memberikan beasiswa melalui Tanoto Foundation ternyata melakukan tindakan penghindaran pajak melalui transfer pricing

\section{Keterbatasan}

Penelitian ini masih memiliki keterbatasan yang dapat mempengaruhi hasil penelitian, yaitu :

1. Banyak perusahaan yang tidak mengungkapkan laporan keuangannya dan mengalami rugi dalam periode tertenntu. sehingga ada yang tidak sesuai dengan kriteria sampel. 
2. Terdapat beberapa perusahaan yang menampilkan rincian kepemilikan saham perusahaannya namun untuk kepemilikan saham yang dimiliki oleh institusi tidak ada.

3. Untuk pengukuran tax avoidance menggunakan CETR masih tidak jauh berbeda dengan menghitung tarif pajak yang dikenakan karena dihitung melalui pph yang dibayarkan perusahaaan dibagi dengan laba sebelum pajak

\subsection{Saran}

Saran yang dapat diberikan antara lain:

1) Bagi pihak manajemen perusahaan non keuangan, apabila pihak manajemen ingi meminimalkan penggunaan hutang dapat dilakukan dengan mengefisienkan investasi.

2) Bagi pihak kreditur, apabila ingin menawarkan hutang ke pihak perusahaan dapat mempertimbangkan tingkat profitabilitas perusahaan karena perusaahan yang profitabilitasnya tinggi lebih mampu melakukan pembayaran atas hutang yang dimiliki.

3) Bagi pihak investor, apabila ingin berinvestasi dapat menjadikan profitabilitas perusahaan sebagai tolak ukur keuntungan yang didapat dari investasi tersebut. Investor hendaknya memilih perusahaan dengan tingkat hutang yang minimal sebab semakin besar hutang maka semakin besar juga resiko yang akan ditanggung oleh investor karena kemungkinan perusahaan tidak mampu membayar hutang-hutangnya.

\section{Daftar Pustaka}

Annisa, NuralifnidaAyudan Lulus Kurniasih. 2012. Pengaruh Corporate Governance terhadap Tax Avoidance. JurnalAkuntansidan Auditing. Vol.8. No.2:95-189.

Budiman, Judi dan Setiyono. 2012. Pengaruh Karakter Eksekutif terhadap Penghindaran Pajak (Tax Avoidance). JurnalUniversitas Islam Sultan Agung.

Darmawan, I.G.H., I.M. Sukartha. 2014. Pengaruh Penerapan Corporate Governance, Leverage, Return on Assets, danUkuran Perusahaan pada Penghindaran Pajak E-Jurnal Akuntansi Universitas Udayana.Vol. 9. No. 1:143-161.
Ghozali, Imam. 2009. Aplikasi Analisis Multivariate dengan Program SPSS. Semarang. Edisi Keempat. Penerbit Universitas Diponegoro.

Handayani, C.D.. Muhammad A.A. dan Mujiyati. 2015. Pengaruh Return on Asset, Karakter Eksekutif, dan Dimensi Tata Kelola Perusahaan yang Baik terhadap Tax Avoidance. Syariah Paper Accounting FEB UMS.

Januarti, Indira. Apriyanti, Dini. 2005. Pengaruh Tanggung Jawab Sosial Perusahaan terhadap Kinerja Keuangan. Jurnal MAKSI. Vol 5 No.2 Hal. 227-243.

Kurniasih, Tommy. Maria, M. Ratnasari. 2013. Pengaruh Return On Assets, Leverage, Corporate Governance, Ukuran Perusahaaan dan Kompensasi Rugi Fiskal pada Tax Avoidance. Buletin Studi Ekonomi. Vol. 18, No. 1.

Lanis, R., and G. Richardson. 2012. Corporate social responsibility and tax aggressiveness: An empirical analysis. Journal of Accounting and Public Policy 31 (1):86-108.

Natalia, Maria. Dkk. 2016. Pengaruh Pengungkapan Tanggung Jawab Sosial Perusahaan terhadap Kinerja Pasar dengan Moderasi Efektifitas Dewan Komisaris dan Independensi Dewan Komisaris. Jurnal Akuntansi Vol.8 No.1 Mei 2016: 45 - 6 Universitas Kristen Maranatha: Bandung

Sari, Ni Putu. 2014. Faktor-faktor yang mempengaruhi struktur modal pada perusahaan non keuangan yang terdaftar di bursa efek indonesia tahun 20082012. Universitas Udayana ; Jakarta.

Saputra,Muhammad Fajir, DKK. 2016. pengaruh corporate governance, profitabilitas dan karakter eksekutif terhadap tax avoidance pada perusahaan yang terdaftar di BEI. Universitas Bung Hatta : Padang.

Wiguna, Putu Putra. 2017. Pengaruh Corporate Social Responsibility, PreferensiRisiko Eksekutif, Dan Capital Intensity Pada Penghindaran Pajak. Universitas Udayana; Jakarta

Wijayanti, Ajeng et al. 2016. PengaruhKarakteristik Perusahaan, GCG dan CSR TerhadapPenghindaranPajak. Seminar Nasional IENACO.

Yoehana, Maretta. 2013. Analisis Pengaruh Corporate Social Responsibility terhadap Aggresivitas Pajak. Universitas Diponegoro. Skripsi Fakultas Ekonomi dan Bisnis. 